\title{
PENGARUH TINGKAT PENDIDIKAN ORANG TUA TERHADAP PENDIDIKAN ANAK DI KELURAHAN PINASUNGKULAN KECAMATAN RANOWULU KOTA BITUNG
}

\author{
Anggreiny C. J. Emor, Apeles Lexi Lonto, Theodorus Pangalila \\ Jurusan PPKn FIS UNIMA
}

\begin{abstract}
ABSTRAK
Penelitian ini bertujuan untuk mengetahui pengaruh tingkat pendidikan orang tua terhadap pendidikan anak di kelurahan Pinasungkulan kecamatan Ranowulu kota Bitung. Penelitian ini menggunakan pendekatan kuantitatif, yaitu metode yang diarahkan untuk memecahkan masalah dengan cara memaparkan atau menggambarkan apa adanya hasil penelitian. Ketepatan penentuan metode ini didasarkan pada pendapat Winarno Surachmat (1982:139), bahwa aplikasi metode ini dimaksudkan untuk penelitan yang tertuju pada pemecahan masalah yang ada pada masa sekarang. Kesimpulan yang diperoleh dari hasil penelitian ini dilihat dari hasil pengujian hipotesis yang dilakukan dengan menggunakan rumus Pearson Product Moment. Dari perhitungan yang telah dilakukan diperoleh $\mathrm{r}_{\mathrm{xy}}=0,753$. Kemudian dilanjutkan mengukur keberartian koefisien dengan menggunkan uji-t, dengan memperoleh hasil $t_{\text {hitung }}=7,323$. Dengan membandingkan $t_{\text {hitung }}$ dengan $\mathrm{t}_{\text {tabel }}$ atau 7,323 dengan 1,683. Karena $t_{\text {hitung }}$ lebih besar dari $t_{\text {tabel }}$ atau 7,323 > 1,683 maka menerima $\mathrm{H}_{\mathrm{a}}$ artinya Terdapat pengaruh yang signifikan antara Tingkat Pendidikan Orang Tua terhadap Pendidikan anak di Kelurahan Pinasungkulan Kecamatan Ranowulu Kota Bitung dan menolak $\mathrm{H}_{0}$ yaitu Tidak Terdapat Pengaruh Yang Signifikan Antara Tingkat Pendidikan Orang Tua terhadap Pendidikan Anak.
\end{abstract}

\section{Kata Kunci: Tingkat Pendidikan Orang Tua, Pendidikan Anak}

\section{PENDAHULUAN}

Menurut Ki Hajar Dewantara dalam Rohman (2013:8) pendidikan adalah usaha menuntun segenap kekuatan kodrat yang ada pada anak baik sebagai individu manusia maupun sebagai anggota masyarakat agar dapat mencapai kesempurnaan hidup. Pendidikan adalah kesadaran untuk mengembangkan kepribadian dan kemampuan di dalam dan luar sekolah dan berlangsung seumur hidup, yang dilaksanakan di dalam lingkungan keluarga, sekolah dan masyarakat. Suatu lembaga pendidikan pasti mengharapkan tercapainya tujuan pendidikan yang mana dapat membantu terwujudnya tujuan nasional. Dari pengertian di atas dapat diambil kesimpulan bahwa tujuan pendidikan adalah untuk membentuk kepribadian dan kemampuan anak. Untuk mencapai tujuan tersebut dapat melalui pendidikan keluarga, sekolah dan masyarakat.
Sejalan dengan paparan di atas, maka dalam Undang-undang RI No. 20 Tahun 2003 tentang sistem pendidikan nasional disebutkan bahwa pendidikan adalah usaha sadar dan terencana untuk mewujudkan suasana belajar dan proses pembelajaran agar peserta didik secara aktif mengembangkan potensi dirinya untuk memiliki kekuatan spiritual keagamaan, pengendalian diri, kepribadian, kecerdasan, akhlak mulia, serta keterampilan yang diperlukan dirinya, masyarakat, bangsa dan Negara.

Dari dua pengertian di atas maka dapat disimpulkan bahwa pendidikan merupakan suatu upaya dalam mempersiapkan sumber daya manusia yang memiliki keahlian dan keterampilan sesuai tuntutan pembangunan bangsa, dimana kualitas suatu bangsa sangat dipengaruhi oleh faktor pendidikan. Perwujudan masyarakat berkualitas tersebut menjadi 
tanggung jawab pendidikan, terutama dalam menyiapkan peserta didik menjadi subyek yang makin berperan menampilkan keunggulan dirinya yang tangguh, kreatif, mandiri, dan profesional pada bidang masing-masing. Upaya peningkatan kualitas pendidikan dapat tercapai secara optimal, apabila dilakukan pengembangan dan perbaikan terhadap komponen pendidikan itu sendiri.

Selanjutnya untuk mewujudkan pengertian pendidikan yang dimaksud, maka lingkungan keluarga (orang tua) merupakan pusat pendidikan yang pertama dan utama bagi seorang anak. Keluarga merupakan proses penentu dalam keberhasilan belajar. Sebagaimana yang diungkapkan oleh Malik Fadjar yang dikutip oleh Melly S.S Rifai (2000) bahwa orang tua dikatakan sebagai pendidik pertama dan utama karena pendidikan yang diberikan orang tua merupakan dasar dan sangat menentukan perkembangan anak selanjutnya.

Peneliti memahami pendidikan secara luas dan umum adalah sebagai usaha sadar yang dilakukan pendidik melalui bimbingan, pengajaran, dan latihan untuk membantu peserta didik mengalami proses pemanusiaan ke arah tercapainya pribadi yang dewasa atau susila yaitu sosok manusia dewasa yang sudah terisi secara penuh bekal ilmu pengetahuan serta memiliki integritas moral yang tinggi sehingga dalam perjalanannya nanti, manusia yang selalu siap baik jasmani maupun rohani.

Keterpaduan pendidikan baik keluarga, sekolah dan masyarakat sangat menentukan keberhasilan dalam dunia pendidikan. Keluarga merupakan lembaga pendidikan tertua, yang pertama dan utama dialami oleh anak dan lembaga pendidikan yang bersifat kodrat. (Suwarno, 1982:66). Sekolah sebagai lembaga pendidikan formal hakekatnya merupakan lembaga yang mendapat kepercayaan dari orang tua untuk mendidik anak-anaknya dengan tanggung jawab yang terbatas, sesuai dengan fungsi dan tujuan lembaga pendidikan tersebut.

Orang tua adalah pendidik pertama, utama dan kodrat (Suwarno, 1982:90). Prestasi belajar anak bukan semata-mata merupakan hasil proses belajar di sekolah saja. Melainkan ditunjang dari peran orang tua di rumah. Peran orang tua terhadap anak terasa sekali bilamana didukung oleh latar belakang pendidikan yang memadai. Karena keberhasilan pendidikan anak tidak semata-mata hanya ditentukan oleh sekolah saja. Orang tua mempunyai andil keberhasilan anaknya. Kadang-kadang tanggung jawab itu kurang disadari oleh orang tua sehingga sering timbul bahwa kurangnya keberhasilan anaknya merupakan akibat dari kurangnya perhatian dan tanggung jawab pengelola pendidikan.

Lebih lanjut Suwarno mengatakan bahwa anak lahir dalam pemeliharaan orang tua dan dibesarkan di dalam keluarga. Orang tua secara langsung memikul tugas sebagai pendidik, baik bersifat sebagai pemelihara, sebagai pengasuh, sabagai pembimbing, sabagai pembina maupun sebagai guru dan pemimpin terhadap anakanaknya. Ini adalah tugas kodrati dari tiap-tiap manusia. Dalam hal ini, peranan orang tua selaku pendidik dalam keluarga adalah pangkal ketentraman dan kedamaian hidup. Untuk menjaga keselamatan keluarga, keluarga berkewajiban mendidik anak-anaknya agar terhindar dari kehancuran.

Berdasarkan pengamatan Penulis di Kelurahan Pinasungkulan selama kurang lebih 4 bulan. melalui Observasi kepada Kepala Kelurahan dan menjalankan angket kepada masyarakat di kelurahan pinasungkulan. Kepala Kelurahan mengatakan jumlah masyarakat di kelurahan pinasungkulan berjumlah 224 KK. Dengan perincian tingkat pendidikan yang tidak tamat SD berjumlah $12 \mathrm{KK}$, yang tamat SD berjumlah $79 \mathrm{KK}$, yang tamat SMP/SMK/SMK berjumlah $110 \mathrm{KK}$, dan yang tamat pendidikan tinggi berjumlah 23 KK. Masalah yang berkaitan dengan tingkat pendidikan anak dilihat dari angket yang diberikan kepada orang tua. Peneliti bertanya kepada orang tua yang memiliki pendidikan rendah dan orang tua tersebut berpikir bahwa pendidikan anak belum terlalu penting dan yang terpenting adalah kehidupan mereka sehari-hari dan lebih memilih anak mereka untuk bantu-bantu berkebun atau usaha sehingga bisa dilihat pendidikan anak mereka rendah juga sedangkan orang tua yang berpendidikan tinggi berpikir bahwa pendidikan anak itu sangat penting karena lewat pendidikan anak bisa mendapat keberhaslian dalam hidup sehingga orang tua yang memiliki pendidikan 
yang tinggi berlomba-lomba untuk membuat anaknya berhasil sampai ke pendidikan tinggi.

Berdasarkan uraian dan pengamatan sementara terhadap tingkat pendidikan orang tua di Kelurahan Pinasungkulan Kecamatan Ranowulu dalam kaitannya dengan pendidikan anak. Untuk mengetahui ada tidaknya pengaruh latar, maka peneliti tertarik meneliti masalah tersebut dengan judul "Pengaruh Tingkat Pendidikan Orang Tua Terhadap Pendidikan Anak Di Kelurahan Pinasungkulan Kecamatan Ranowulu Kota Bitung".

\section{KAJIAN TEORI \\ Pengertian Pendidikan}

Secara etimologis atau kebahasaan, kata pendidikan berasal dari kata dasar 'didik' yang mendapat imbuhan awalan dan akiran pe-an. Berubah menjadi kata kerja 'mendidik' yang berarti membantu anak untuk menguasi aneka Pengetahuan, ketrampilan, sikap, dan nilai yang diwarisi dari keluarga dan masyarakatnya. Istilah ini pertama kali muncul dengan bahasa Yunani yaitu 'paedagogiek' yang berarti ilmu menuntun anak, dan 'paedagogia' adalah pergaulan dengan anak-anak, sedangkan orangnya yang menuntun/mendidik anak adalah 'paedagog'. Orang Romawi melihat pendidikan sebagai educare, yaitu mengeluarkan dan menuntun, tindakan merealisasikan potensi anak yang dibawa waktu dilahirkan di dunia. Bangsa Jerman melihat pendidikan sebagai Erziehung yang setara dengan edacare, yakni membangkitkan kekuatan terpendam atau mengaktifkan kekuatan/potensi anak. Dalam bahasa Inggris dikenal education (kata benda) dan educate (kata kerja yang berarti mendidik (Rohman, 2013:5).

Dalam kamus bahasa Inggris, Offord Learner's Pocket Dictionary kata pendidikan diartikan sebagai pelatihan dan pembelajaran. (Education is training and instruction). Sedangkan dalam kamus besar Bahasa Indonesia, pendidikan diartikan sebagai proses perubahan sikap dan tingkah laku seseorang atau kelompok dalam usaha mendewasakan manusia melalui proses pengajaran dan pelatihan.

Selanjutnya Carter V. Good membedakan pengertian pendidikan dalam dua hal: (1)
Pendidikan adalah seni, praktek, atau profesi pengajaran. (2) Pendidikan adalah ilmu yang sisrematis atau pengajaran yang berhubungan dengan prinsip-prinsip dan metode-metode mengajar, pengawasan dan pembimbingan siswa (Rohman 2013:6).

John Dewey dalam Soedijarto (2007:2), mengartikan pendidikan adalah suatu proses pembentukan kecakapan-kecakapan fundamental baik secara intelektual maupun emosional ke arah alam dan sesama manusia. Gielen and S. Strasser, menyebut pendidikan sebagai segala usaha orang dewasa dalam pergaulannya dengan anak-anak untuk memimpin perkembangan jasamani dan rokhaninya ke arah kedewasaan.

Dadang Supardan (2005:43) mengutip John S. Brubacher, mengartikan pendidikan sebagai proses dalam mana potensi-potensi, kemampuan, kapaistas yang mudah dipengaruhi oleh kebiasaan-kebiasaan, disempurnakan dengan kebiasaan yang baik dengan alat disusun sedemikian rupa dan digunakan manusia untuk menolong orang lain atau diri sendiri dalam mencapai tujuan yang ditetapkan.

Philip H. Cooms dalam As'ari Djohar (2007:376) mengatakan pendidikan secara popular disamakan dengan persekolahan (schooling)yang lazim dikenal dengan pendidikan formal, yang bergerak dari tingkat pertama sekolah dasar hingga mencapai tingkat terakhir dari perguruan tinggi. Sedangkan Stephens, pendidikan disamakan dengan belajar dan mengajar yaitu peristiwa wajar yang terjadi pada manusia secara terus-menerus berlangsung dengan cara yang spontan, bahkan tanpa disadari melakukannya.

\section{Konsep Orang Tua}

Orang tua merupakan pendidik utama dan pertama bagi anak-anak mereka, karena dari merekalah anak mula-mula menerima pendidikan. Dengan demikian bentuk utama dari pendidikan terdapat dalam kehidupan keluarga. Pada umumnya pendidikan dalam rumah tangga itu bukan berpangkal tolak dari kesadaran dan pengertian yang lahir dari pengetahuan mendidik, melainkan karena secara kodrati suasana dan strukturnya memberikan kemungkinan alami membangun situasi 
pendidikan. Situasi pendidikan itu terwujud berkat adanya pergaulan dan hubungan pengaruh mempengaruhi secara timbal balik antara orang tua dan anak (Haryono, 1993:3)

Orang tua Dalam kamus besar bahasa Indonesia (Poerdarmita, 1987:688) artinya ayah dan ibu. Mely S.S. Rifai (2000:85) mengatakan orang tua memegang peranan yang penting dan amat berpengaruh atas pendidikan anakanaknya. Sejak seorang anak lahir, ibunyalah yang selalu ada disampingnya. Oleh karena itu ia meniru perangai dan biasanya, seorang anak lebih cinta kepada ibunya, apabila itu menjalankan tugasnya dengan baik. Ibu merupakan orang yang mula-mula dikenal anak, yang mula-mula menjadi temannya dan mulamula dipercayainya. Apapun yang dilakukan ibu dapat dimanfaatkannya, kecuali apabila ia ditinggalkan. Dengan memahami segala sesuatu yang terkandung di dalam hati anaknya, juga jika anak telah mulai agak besar, disertai kasih sayang, dapatlah ibu mengambil hati anaknya untuk selama-lamanya.

Lebih lanjut lagi Mely S.S. Rifai (2000:86) mengatkan bahwa pengaruh ayah terhadap anaknya besar pula. Di mata anaknya ia seorang yang tertinggi gengsinya dan terpandai diantara orang-orang yang dikenalnya. Cara ayah melakukan pekerjaannya sehari-hari berpengaruh pada cara pekerjaan anaknya. Ayah merupakan penolong utama, lebih-lebih bagi anak yang agak besar, baik laki-laki maupun perempuan, bila mau mendekati dan dapat memahami hati anaknya.

Pada dasarnya kenyataan-kenyataan yang dikemukakan di atas itu berlaku dalam kehidupan keluarga atau rumah tangga dengan yang bagaimanapun juga keadaannya. Hal itu menunjukkan ciri-ciri dari watak rasa tanggung jawab dari setiap orang tua atas kehidupan anakanak mereka untuk masa kini dan masa mendatang, bahkan para orang tua umumnya merasa bertanggung jawab atas segala dari kelangsungan hidup anak-anaknya. Karenanya tidaklah diragukan bahwa tanggung jawab pendidikan secara mendasar terpikul kepada orang tua (Sanapiah Faisal 1981).

Di tilik dari hubungan dan tanggung jawab orang tua kepada anak, maka tanggung jawab pendidikan itu pada dasarnya tidak bisa dipikulkan kepada orang lain, sebab guru dan pemimpin umat umpamanya, dalam memikul tanggung jawab pendidikan yang dipikul oleh para pendidik selain orang tua adalah merupakan pelimpahan dari tanggung jawab orang tua yang karena satu dan lain hal tidak mungkin melaksanakan pendidikan anaknya secara sempurna.

Dari seluruh pengertian orang tua menurut para ahli dapat peneliti simpulkan bahwa orang tua merupakan pendidik utama bagi anak sejak anak lahir sampai dewasa karena lewat orang tua anak dapat memiliki sifat dan kepribadian yang baik dan itu semua di ajarkan oleh orang tua.

\section{Jalur, Jenis, dan Jenjang Pendidikan}

Dalam undang-undang Sistem Pendidikan Nasional No. 20 tahun 2003, ketentuan tentang jalur, jenis dan jenjang pendidikan terdapat dalam Bab VI pasal 13, 14, 15, dan 16.

\section{Jalur Pendidikan}

Sesuai dengan pasal 13, ayat $1 \mathrm{UU}$ Sisdiknas No. 20 tahun 2003, Jalur pendidikan adalah wahana yang dilalui peserta didik untuk mengembangkan potensi diri dalam suatu proses pendidikan yang sesuai dengan tujuan pendidikan. Jalur pendidikan terdiri atas pendidikan formal, nonformal, dan informal yang dapat saling melengkapi dan memperkaya. Hal ini juga senada dengan pendapat Philip $\mathrm{H}$. Coombs seperti yang dikutip Rohman (2013:221) yang menyebut ada tiga jalur pendidikan yuatu formal, nonformal, dan informal.

Menurut Sanapiah Faisal (1981), pada jalur pendidikan formal yang umumnya menunjuk pada pendidikan persekolahan. Pada jalur pendidikan persekolahan ini memiliki karakteristik antara lain sudah terstardardisasi sedemikian rupa paling tidak dalam wujud legalitas formalnya, dalam jenjang-jenjangnya; lamama belajarnya, paket kurikulumnya persyaratan unsur-unsur pengelolaannya, persyaratan usia dan tingkat kemampuan enrolmentnya, perolehan dan keberartian nilai dari kredensialnya, prosedur evaluasi hasil belajarnya, dan sekuensi penyajian materi dan latihan-latihannya. Pendidikan formal memiliki 
persyararan-persyaratan organisasi dan pengelolaan yang relatif ketat, lebih formalistis, dan lebih terikat pada legalitas formaladministratif.

Sedangkan pendidikan nonformal Sanapiah Faisal (1981), paket pendidikannya berjangka pendek, setiap program pendidikannya merupakan suatu paket yang sangat spesifik dan biasanya lahir dari kebutuhan yang mendadak, persyaratan enrolmentnya lebih fleksibel balik dalam usia maupun tingkat kemampuan, persyaratan unsurunsur pengelolanya juga lebir fleksibel, sekuensi materi pelajaran lebih luwes, tidak berjenjang kronologis, serta perolehan dan keberartian nilai kredensialnya tidak begitu terstandardisi. Sehingga secara umum bias dikatakan lebih lentur dan berjangka pendek.

Adapun pendidikan informal menurut UU

No. 20 tahun 2003 Pasal 1:13 adalah jalur pendidikan melalui keluarga dan lingkungan. Pendidikan informal sama sekali tidak terorganisir secara strukrural, tidak terdapat penjenjangan kronologis, tidak mengenal adanya kredensial, lebih merupakan pengalaman belajar individual-mandiri, pembelajarannya sangat natural tidak buatan sebagaimana pada pendidikan formal dan nonformal (Rohman 2013:223).

Ketiga jalur pendidikan formal, norformal, dan informal di atas beberapa ahli ada yang menyamakan dengan istilah jenis pendidikan yaitu jenis formal, nonformal, dan informal. Jenis formal wujudnya adalah sekolah, jenis non-formal adalah lembagalembaga kursus dan pelatihan di masyarakat, sedang jenis informal wujudnya adalah lembaga keluarga.

Berbeda dengan hal di atas pada UndangUndang nomor 2 tahun 1989 tentang Sistem Pendidikan Nasional mengenal jalur pendidikan hanya dua, yaitu: (1) jalur pendidikan sekolah, dan (2) jalur pendidikan luar sekolah. Namun ada kemiripan dengan penjelasan sebelumnya tentang formal, nonformal, dan informal. Sebab jalur pendidikan sekolah mempunyai karakteristik sebagaimana pendidikan formal, serta jalur pendidikan luar sekolah memiliki ciri-ciri sebagaimana pendidikan nonformal dan informal.

\section{Jenis Pendidikan}

Rohman (2013:228) mengemukakan jenis pendidikan adalah kelompok yang didasarkan pada kekhusan tujuan pendidikan sratu satuan pendidikan. Jenis pendidikan mencakup pendidikan umum, kejuruan, akademi, profesi, vokasi, keagamaan, dan khusus. Pendidikan umum merupakan pendidikan yang mengutamakan perluasan pengetahuan dan peningkatan keterampilan peserta didik dengan pengkhususan yang diwujudkan pada tingkattingkat akhir masa pendidikan. Pendidikan kejuruan merupakan pendidikan yang mempersiapkan peserta didik untuk dapat bekerja dalam bidang tertentu. Pada jenis formal, pendidikan umum antara lain berbentuk Sekolah Menengah Atas (SMA). Sedangkan jenis kejuruan antara lain berbentuk Sekolah Menengah Kejuruan (SMK).

Selanjutnya Rohman

mengemukakan jenis pendidikan juga mencakup pendidikan akademik dan profesi. Pendidikan akademik adalah jenis pendidikan yang diarahkan terutama pada penguasaan ilmu pengetahuan, sedangkan pendidikan profesi merupakan pendidikan yang diarahkan terutama pada kesiapan penerapan keahlian tertentu. Pendidikan keagamaan merupakan pendidikan yang mempersiapkan peserta didik untuk dapat menjalankan peranan yang menuntut penguasaan pengetahuan khusus tentang ajaran agama yang bersangkutan. Pendidikan keagamaan diselenggarakan oleh Pemerintah dan/atau kelompok masyarakat dari pemeluk agama, sesuai dengan peraturan perundangundangan. Pendidikan keagamaan berfungsi mempersiapkan peserta didik menjadi anggota masyarakat yang memahami dan mengamalkan nilai-nilai ajaran agamanya dan/atau menjadi ahli ilmu agama.

Selain dengan semua yang telah disebutkan di atas, terdapat lagi satu jenis pendidikan yaitu pendidikan khusus dan pendidikan dengan layanan khusus. Pendidikan khusus merupakan pendidikan bagi peserta didik yang memiliki tingkat kesulitan dalam mengikuti proses pembelajaran karena kelainan fisik, emosional, mental, sosial, dan/atau 
memiliki potensi kecerdasan dan bakat istimewa (Sanapiah Faisal, 1981).

\section{Jenjang Pendidikan}

UU No 20 Tahun 2003 Pasal 1:8 jenjang pendidikan adalah tahapan pendidikan yang ditetapkan berdasarkan tingkat perkembangan peserta didik, tujuan pendidikan yang akan dicapai, dan kemampuan peserta didik yang akan dikembangkan. Jenjang pendidikan formal terdiri atas pendidikan dasar, pendidikan menengah, dan pendidikan tinggi. Sedangkan pada pendidikan nonformal dan informal tidak mengenal jenjang.

Pendidikan dasar merupakan jeniang pendidikan yang paling dasar yang mendasari jenjang pendidikan berikutnya. Sebagaimana disebutkan Undang-Undang Indonesia Nomor 20 tahun 2003 pada pasal 17 ayat (1) dan bahwa: "Pendidikan dasar merupakan jenjang pendidikan melandasi jenjang pendidikan menengah. Pendidikan berbentuk Sekolah Dasar (SD) atau bentuk lain sederajat, Sekolah Menengah (SMP) atau bentuk lain sederajat. Pendidikan menengah adalah pendidikan formal yang merupakan kelanjutan dari pendidikan sebelumnya yaitu pendidikan dasar.

Pendidikan menengah terdiri atas pendidikam menengah umum dan pendidikan menengah kejuruan. Pendidikan menengah umum berbentuk Sekolah Menengah Atas (SMA) atau bentuk lain yang sederajat. Sedangkan pendidikan menengah kejuruan berbentuk Sekolah Menengah Keiuruan (SMK) atau bentuk lain yang sederajat (Pasal 18:3 UU No 20 Tahun 2003).

Pendidikan tinggi adalah jenjang pendidikan formal setelah pendidikan menengah dan merupakan jenjang pendidikan tertinggi di Indonesia. Pendiikan tinggi mencakup program pendiikan diploma, sarjana, magister, spesialis dan doctor yang diselenggarakan oleh pendiikan tinggi. Pendiikan tinggi diselenggarakan dengan sistem terbuka. Perguruan Tinggi dapat berbentuk Akademi, Politeknik,Sekolah Tinggi, Institut, Atau Universitas (Pasal 20 UU Nomor 20 Tahun 2003).

\section{Tingkat Pendidikan Orang Tua}

Dalam Kamus Umum Bahasa Indonesia, tingkat pendidikan adalah jenjang pendidikan yang dialami dalam suatu lembaga formal (maupun informal). Sedangkan orang tua diartikan ayah-ibu kandung. Adapun tingkat pendidikan orang tua yang dimaksud disini adalah jenjang pendidikan formal yang dialami orang tua yaitu tingkat Pendidikan Dasar (lulusan SD/MI dan SMP/MTs), tingkat pendidikan menengah (SMA/MA/SMK atau lainnya yang sederajat) dan tingkat pendidikan tinggi (perguruan tinggi, diploma atau sarjana), jenjang pendidikan informal dan jenjang pendidikan non formal.

Seperti yang kita ketahui bahwa setiap orang tua mempunyai tingkat kehidupan yang berbeda-beda. Ada yang berasal dari keluarga mampu, dan ada yang berasal dari keluarga kurang mampu. Ada yang berasal dari keluarga berpendidikan tinggi, ada pula yang berasal dari keluarga berpendidikan rendah. Kesemuanya itu mengakibatkan perbedaan tingkat pendidikan yang dialami seseorang. Bagi mereka yang berasal dari keluarga mampu banyak mendapatkan kesempatan yang setinggitingginya untuk sekolah, karena biaya mendukung. Dan sebaliknya pula bagi mereka yang berasal dari keluarga yang kurang mampu, tidak banyak mendapatkan kesempatan yang tinggi untuk sekolah karena biaya yang tidak mendukung.

Demikian juga bagi mereka yang berasal dari keluarga berpendidikan tinggi, merekapun mungkin akan memperoleh kesempatan untuk sekolah yang tinggi karena orang tuanya akan mempunyai tanggung jawab terhadap anakanaknya. Akan tetapi, bagi mereka yang berasal dari keluarga kurang pendidikannya, mungkin mereka kurang banyak mendapat kesempatan untuk sekolah karena orang tua kurang tahu akan tanggung jawabnya pada pendidikan anakanaknya. Oleh karena itu pengalaman yang dialami seseorang khususnya pengalaman pendidikan berbeda-beda, baik dilihat dari jalur maupun jenjang atau tingkat pendidikannya.

Orang tua merupakan pendidik utama dan pertama bagi anak-anak mereka, karena dari merekalah anak mula-mula menerima 
pendidikan. Dengan demikian bentuk pertama dri pendidikan terdapat dalam kehidupan keluarga. Kegagalan orang tua dalam membina anak untuk menjadikan anak yang baik tidak akan terjadi manakala orang tuanya menjalankan fungsi atau perannya sebagai orang tua yang bertanggung jawab terhadap anaknya (Suwarno, 1992:91).

Dalam keluarga, orang tua mempunyai peranan yang sangat vital terhadap kemajuan keluarganya yang meliputi pendidikan anakanaknya. Sehingga menurut M. Ngalim Purwanto (1997), orang tua dapat dikatakan sebagai pendidik sejati, pendidik karena kodratnya. Setiap orang tua memiliki keinginan agar anak-anaknya tumbuh berkembang menjadi anak-anak yang berprestasi dalam pendidikan. Orang tua ingin agar anak-anak mereka dapat meraih prestasi yang maksimal di sekolah. Mereka pun mengharapka agar anakanaknya memiliki kepribadian dan akhlak yang mulia yang dicintai oleh banyak orang.

Orang tua yang mempunyai tingkat pendidikan yang tinggi dan pengalaman yang banyak tentunya akan mempengaruhi gaya kepemimpinannya di dalam keluarga. Sebab semakin tinggi tingkat pendidikan orang tua maka akan bertambah luas pandangan dan wawasannya, termasuk dalam mengatur keuarganya. tuanya menjalankan fungsi atau perannya sebagai orang tua yang bertanggung jawab terhadap anaknya. Dalam keluarga, orang tua mempunyai peranan yang sangat vital terhadap kemajuan keluarganya yang meliputi pendidikan anak-anaknya (Sanapiah Faisal, 1981).

Menurut peneliti tingkat pendidikan orang tua sangat penting bagi pendidikan anakanaknya karena jika tingkat pendidikan orang tua rendah cara berpikir dan wawasan mereka belum luas sehingga cara mendidik anak belum sempurna maka banyak anak-anak mereka belum berhasil dalam studi. Sedangkan tingkat pendidikan orang tua yang tinggi sudah memiliki cara berpikir dan mempunyai wawasan yang luas sehingga cara mendidik anak mereka sangat baik dan anak-anak mereka bisa berhasil dalam pendidikan.

\section{Pentingnya Pendidikan}

Berdasarkan teori-teori yang telah dipaparkan di atas berbagai pandangan mengenai hakikat manusia yang berbeda-beda lahirlah berbagai rumusan tentang tujuan proses pendidikan itu. Pandangan-pandangan tersebut tentang pendidikan dapat diurakan sebagai berikut:

\section{Pendidikan sebagai Transmisi Kebudayaan}

Pandangan ini memang sangat umum dan popular di dalam suatu masyarakat tradisional. Seperti yang terjadi di dalam masyarakat tradisional yang belum mengenal lembaga pendidikan sekolatu pendidikan terjadi di dalam lingkungan keluarga dan di dalam lingkungan masyarakatnya yang terbatas. Proses pendidikan dinilai sebagai proses mentransmisikan nilainilai budaya yang telah terakumulasi dari satu generasi ke generasi lainnya. Perubahan di dalam masyarakat memang terjadi tetapi secara lambat dan sangat menguras tenaga bagi suafu masyarakat untuk mengubahnya. Di samping itu, nilai-nilai positif yang melekat pada suatu masyarakat tradisional, mempunyai banyak kelemahan, Iebih-lebih di dunia yang penuh keterbukaan dewasa ini.

Kemajuan akal manusia, kemajuan ilmu pengetahuan serta kemajuan teknologi komunikasi telah membuat dunia ini sebagai suatu kampung besar (big village) bahkan dalam suatu dunia yang terbuka tidak memungkinkan suatu masyarakat statis untuk tidak berubah. Masyarakat berubah sangat cepat sehingga kadang-kadang manusia kehilangan pegangan sehingga ketiadaan identitasnya dan terhempas di dalam dunia yang kosong. Globalisasi telah menelorkan kehampaan demikian pendapat Ritzer yang dikutip oleh Tilaar dan Riant Nugroho (2008:27). Persoalan dewasa ini ialah bagaimana mengembangkan kepribadian seseorang di tengah-tengah ancaman globalisasi yang menghancurkan identitas seseorang sehingga mau tidak mau perkembangannya akan terhambat.

\section{Pendidikan sebagai Pengembangan Kepribadian}

Proses pendidikan sebagai pengembangan kepribadian mencakup upaya yang sangat luas. 
Terdapat banyak teori mengenai kepribadian, strukturnya, pengembangannya, tujuannya dan sebagainya sehingga proses pendidikan sebagai pengembangan kepribadian mencakup berbagai upaya yang luas. Oleh sebab itu, perumusan mengenai proses Pendidikan sebagai proses pengembangan kepribadian menjadi sangat luas. Tujuannya adalah benar bahwa manusia itu haruslah mengembangkan kepribadiannyadi dalam pengertian etis sehingga dia terbagi bukan hanya dapat berkembang tetapi juga dapat menyumbangkan sesuatu yang berharga untuk masyarakatnya (Tilaar dan Riant Nugroho, 2008:28).

Selanjutnya dikemukakan bahwa pengembangan kepribadian bukan hanya berarti perkembangan kepribadian dalam arti personal tetapi perkembangan kepribadian yang menyangkut aspek-aspek personal dan sosial. Perkembangan keduanya harus seimbang, saling mengisi sehingga terjadi simbiosis antara kepribadian yang berkembang dan manfaat yang diperoleh masyarakat dari perkembangan kepribadian itu.

\section{Pendidikan sebagai Pengembangan Akhlak Mulia serta Religius}

Dalam masyarakat modern yang telah berdiferensiasi, tugas utama lembaga pendidikan adalah pengembangan akal-budi manusia sehingga dia dapat mengembangkan kepribadiannya. Dalam masyarakat maju yang telah berdiferensiasi, pengembangan kepribadian manusia bukan hanya terjadi di dalam lembaga-lembaga pendidikan tetapi juga dalam berbagai lembaga yang berada dalam masyarakat. Salah satu lembaga di dalam masyarakat modern adalah lembaga agama. Tugas dari lembaga agama sebagai frembaga pendidikan adalah pengembangan akhlak mulia dari para anggotanya (Tilaar dan Riant Nugroho, 2008:29).

\section{Pendidikan sebagai Pengembangan Warga Negara yang Bertanggungjawab}

Hakikat manusia adalah sebagai makhluk pribadi dan sekaligus sebagai makhluk sosial. Artinya manusia tidak dapat berkembang sepenuhnya terisolasi dari masyarakatnya. Manusia merupakan anggota atau warga dari berbagai keanggotaannya dalamhidup bermasyarakat dan salah satu keanggotaannya tersebut adalah sebagai warga negara.

Setiap warga negara mempunyai hak dan kewajibannya masing-masing. Negara melindungi dan memfasilitasi perkembangan individu sepenuhnya. Ini adalah tanggung jawab negara. Sebaliknya, setiap warga negara mempunyai tanggung jawab untuk memelihara ketertiban di dalam masyarakat sehingga negara dapat melaksanakan fungsinya dalam melindungi serta memfasilitasi perkembangan warganegaranya termasuk penyelenggaraan pendidikan yang dibutuhkan oleh warga anggotanya. Warga negara bukan hanya dapat tetapi boleh dan harus menuntut negara untuk melindungi hak-hak asasi kemanusiaannya. Oleh sebab itu, setiap warga Negara Indonesia mempunyai kewajiban untuk menjadi warga negara yang baik dengan memenuhi berbagai kewajiban untuk negara seperti membayar pajak yang setia, patuh terhadap Undang-Undang, menghormati simbol-simbol negara sebagai kesepakatan bersama di dalam hidup bersama dalam masyakarat bangsa (Tilaar dan Riant Nugroho, 2008:31).

\section{Pendidikan sebagai Mempersiapkan Pekerja-Pekeria yang Terampil dan Produktif}

Abad XXI adalah abad perkembangan industri yang pesat ditopang oleh kemajuan ilmu pengetahuan dan teknologi. Kemajuan induski yang pesat dalam dunia yang terbuka telah melahirkan budaya baru yaitu budaya materialisme dan komersiaiisme yang kemudian memicu lahirnya gaya hidup baru (life style) yang sangat konsumeristik. Dunia yang rata dan dikuasai oleh pasar bebas menjadikan etika persaingan sebagai tuhan baru dalam memacu hasil-hasil produksi yang semakin berkuaritas dan terjangkau oleh rakyat banyak.

Sejalan dengan itu pula, perkembangan yang pesat dunia bisnis yang bermotifkan keuntungan (profit) telah melahirkan perusahaan-perusahaan raksasa dunia multinasional dengan segala keuntungan dan aibnya. Perubahan budaya global yang komersialistis itu merambah dunia pendidikan. Pendidikan memberikan respons tuntutan 
terhadap pekerja-pekerja yang terampil sehingga proses pendidikan berubah menjadi proses pelatihan untuk menghasilkan pekerjapekerja yang diminta oleh perkembangan industri.

Pekerjaan bukanlah tujuan akhir dari kehidupan manusia tetapi sebagai sarana dari perwujudan kemanusiaan seseorang. Masingmasing orang dikaruniai talenta dan dengan talenta itu manusia dapat mewujudkan kemanusiaannya baik untuk dirinya sendiri maupun untuk sesamanya. Manusia yang merdeka, adalah manusia yang mengembangkan keberdayaannya melalui pekerjaan yang dimilikinya sehingga dia dapat sepenuhnya mengabdikan dirinya bagi penyempumaan kehidupan pribadinya dan juga sebagai anggota masyarakat yang berguna dan bertanggung jawab (Tilaar dan Riant Nugroho, 2008:34).

\section{Pendidikan adalah Pengembangan Pribadi Paripurna atau Seutuhnya}

Pengertian paripurna atau seutuhnya lebih merupakan istilah politik daripada istilah yang mengandung nilai-nilai saintifik. Pertama-tama ialah kenyataan bahwa tidak ada manusia atau pribadi yang sempurna. Manusia diciptakan dan dilahirkan dengan dikaruniai bakat yang berbeda-beda. Pengembangan manusia atau pengembangan kepribadian manusia seutuhnya akan rebih tepat apabila dikatakan "pengembangan pribadi sebagaimana adanya". Karena keberadaan manusia adalah keberadaan dalam keragaman maka pengembangan kepribadian manusia dalam keragamannya berarti menitikberatkan kepada kreativitas manusia dan bertanggung jawab terhadap kehidupannya. Pendidikan manusia seutuhnya atau pendidikan kepribadian paripurna mengasumsikan keseragaman manusia yang bertentangan dengan keragaman manusia (Tilaar dan Riant Nugroho, 2008:36).

\section{Pendidikan Sebagai Proses Pembentukan Manusia Baru}

Pemahaman tentang pendidikan sebagai pembentukan manusia baru dipahami dari fakta bahwa pendidikan adalah sebuah proses yang melekat pada setiap kehidupan bersama dan berjajan sepanjang perjalanan umat manusia. John Dewey yang dikutip Tilaar mengemukakan bahwa pendidikan dapat dipahami sebagai sebuah upaya "konservatif" dan "progresif" dalam bentuk pend'idikan sebagai pendidikan sebagai formasi, sebagai rekapitulasi dan retrospeksi dan sebagai rekonstruksi (Tilaar dan Riant Nugroho, 2008:38).

Menurut peneliti, pendidikan sangat penting bagi setiap orang karena lewat pendidikan setiap orang dapat memiliki sifat dan karakter yang baik dalam keluarga atau bermasyarakat. Selain itu pendidikan sangat penting bagi keberhasilan setiap orang baik dalam pekerjaan atau keluarga karena lewat pendidikan yang didapatkan dari sekolah atau dari keluarga bisa di tuangkan dalam pekerjaan setiap hari.

\section{METODE PENELITIAN}

Metode Metode penelitian ini menggunakan pendekatan kuantitatif, Yaitu metode yang diarahkan untuk memecahkan masalah dengan cara memaparkan atau menggambarkan apa adanya hasil penelitian. Ketepatan penentuan metode ini didasarkan pada pendapat Winarno Surachmat (1982:139), bahwa aplikasi metode ini dimaksudkan untuk penelitan yang tertuju pada pemecahan masalah yang ada pada masa sekarang.

Untuk mengumpulkan data yang diperoleh dalam penelitian ini, maka peneliti menggunakann beberapa instrument penelitian antara lain: Observasi, Yaitu dengan cara mengadakan observasi di lokasi penelitian, untuk lebih meyakini permasalahan yang sedang diteliti. Angket diberikan kepada orang tua/dan atau wawancara untuk memperoleh informasi mengenai pentingnya pendidikan. Angket dibuat dengan skala Likert yang mempunyai lima kemungkinan jawaban yaitu: Sangat Setuju, Setuju, Tidak tahu, Tidak setuju, Sangat tidak setuju. Ini dimaksud untuk menghindari kecenderungan responden bersikap ragu-ragu dan tidak mempunyai jawaban yang jelas.

\section{HASIL PENELITIAN DAN PEMBAHASAN Deskripsi Hasil Penelitian Dan Analisis Data}

Data yang terkumpul melalui penelitian dan penyebaran angket dalam penelitian 
kemudian diberikan pada setiap jawaban. Hasilnya kemudian dijadikan bahan dalam penelitian. Data hasil observasi tentang tingkat pendidikan orang tua merupakan data variabel $\mathrm{X}$ sedangkan pengumpulan data variabel $\mathrm{Y}$ melalaui sebaran angket. Data variabel $X$ dan variabel Y merupakan data mentah. Dalam perhitungan statistik data mentah tersebut diubah ke dalam skor baku atau angka baku. Adapun hasil pengolahan data variabel penelitian tersebut adalah sebagai berikut:

\section{Tingkat Pendidikan Orang Tua (Variabel X)}

Berdasarkan observasi yang dilakukan oleh peneliti Kel. Pinasungkulan Kec. Bitung Barat. Diperoleh data jumlah kepala keluarga adalah $224 \mathrm{KK}$, dengan perincian tingkat pendidikan sebagai berikut :
1. Tidak tamat SD
$=12 \mathrm{KK}$
2. Tamat SD
$=79 \mathrm{KK}$
3. Tamat SMP/SMA/SMK $=110 \mathrm{KK}$
4. Tamat pendidikan tinggi $=23 \mathrm{KK}$

Dalam pengolahan data tingkat pendidikan orang tua diberikan skor 1 s/d 4 sesuai dengan jenjang pendidikan (Lampiran 2). Tingkat pendidikan orang tua (variabel terikat atau "X") menunjukkan bahwa skor tertinggi adalah 4 (Tamat pendidiakan tinggi) dan terendah 1 (Tidak tamat SD). Jumlah skor keseluruhan 111 dengan skor rata-rata (mean) 2,58 , titik tengah (median) 3 , nilai yang sering muncul (mode) 3 (muncul selama 14 kali) simpangan baku (standar deviasi) keseluruhan adalah 1,01 , tingkat penyebaran data (variance) $=1,01$, rentangan (range) 3 (data tertinggi dikurangi data terendah.

\section{Pendidikan anak (Variabel Y)}

Sebagaimana data (Lampiran 3) tentang pendidikan anak yang diperoleh melalui sebaran angket. Data tersebut menjadi variabel bebas atau "Y", nilai tertinggi adalah 91 dan terendah 58. Jumlah nilai keseluruhan 3316 dengan skor rata-rata (mean) 77,12, titik tengah (median) 78, nilai yang sering muncul (mode) 86 (muncul selama 6 kali) simpangan baku (standar deviasi) adalah 8,559, tingkat penyebaran data $($ variance $)=73,248$, rentangan $($ range $) 33$.

Sebaran data tentang pendidikan anak dibagi kedalam 6 kelas interval yaitu $58-63$ sebanyak 5 responden, $64-69$ sebanyak 2 responden, 70 - 75 sebanyak 8 responden, $76-$ 81 sebanyak 13 responden, 82 - 87 sebanyak 12 responden, 89 - 91 sebanyak 3 responden

\section{Pengujian Normalitas}

Uji normalitas distribusi frekuensi dilakukan untuk mengetahui normal atau tidaknya distribusi data yang menjadi syarat untuk menentukan jenis statistik yang digunakan dalam analisis lebih lanjut. Data yang perlu di uji normalitas frekuensi dalam penelitian ini yaitu kelompok data (Y) Pentingnya Pendidikan Anak. Perhitungan uji normalitas distribusi menggunakan rumus chikuadrat, perhitungan dilakukan dengan tahapantahapan.

1. Chi-kuadrat hitung $\left(\chi^{2}\right.$ hitung $)$

$$
\begin{aligned}
& \chi^{2}=\sum_{i=1}^{k} \frac{(f o-f e)^{2}}{f e} \\
& \chi^{2} \\
& \frac{(5-1,78)^{2}}{1,78}+\frac{(2-5,52)^{2}}{5,52}+\frac{(8-10,40)^{2}}{10,40}+\frac{(13-11,94)^{2}}{11,94}+ \\
& \frac{(12-8,34)^{2}}{8,34}+\frac{(3-2,78)}{2,78} \\
& \chi^{2}=5,825+2,245+0,554+0,092+1,606+ \\
& 0,017=10,339
\end{aligned}
$$

Dengan membandingkan $\chi^{2}$ hitung dengan $\chi_{\text {tabel }}^{2}$ untuk $\alpha=0,01$ dan derajat keabsahan (dk) $=\mathrm{k}-1=6-1=5$, maka pada tabel chi kuadrat didapat $\chi^{2}$ tabel $=15,086$ dengan kriteria pengujian sebagai berikut :

Jika $\chi_{\text {hitung }}^{2} \geq \chi_{\text {tabel }}^{2}$ artinya Distribusi Data Tidak Normal

Jika $X^{2}$ hitung $\leq \chi_{\text {tabel }}^{2}$ artinya Distribusi Data Normal.

Ternyata $\chi_{\text {hitung }}^{2}<\chi_{\text {tabel }}^{2}$ atau $10,339<15,086$ maka data "Pentingnya Pendidikan Anak" berdistribusi normal.

\section{Pengujian Linieritas}

Pengujian linieritas menggunakan persamaan regresi sederhana variabel $\mathrm{Y}$ (Pentingnya Penidikan Anak) atas variabel $\mathrm{X}$ (Tingkat Peniikan Orang Tua).

Dari hasil perhitungan data diperoleh $F_{\text {hitung }}=0,62$. Jika $F_{\text {hitung }}<F_{\text {tabel }}$ artinya data berpola linear $(\alpha)=0,05$. Karena $0,62<$ dari 
3,25 maka variabel Tingkat Pendidikan Orang

Tua Terhadap Pendidikan anak berpola "Linear".

\section{Pengujian Hipotesis}

Analisis korelasi yang digunakan yaitu PPM (Person Product Momen). Perhitungan Uji Hipotesis

$$
\begin{gathered}
\frac{\mathrm{r}_{\mathrm{xy}}}{n\left(\sum X Y\right)-\left(\sum X\right) \cdot\left(\sum Y\right)} \overline{\sqrt{\left\{n \cdot \sum X^{2}-\left(\sum X\right)^{2}\right\} \cdot\left\{n \cdot \sum Y^{2}-\left(\sum Y\right)^{2}\right\}}} \\
= \\
\frac{43(8832)-(111) \cdot(3316)}{\sqrt{\left(43.329-(111)^{2} \cdot(43 \cdot 258794)-(3316)^{2}\right.}} \\
=\quad 379776-368076 \\
\sqrt{(14147-12321) \cdot(11128142-10995856)} \\
=\frac{11700}{\sqrt{(1826) \cdot(132286)}} \\
=\frac{11700}{\sqrt{241554236}} \\
=\frac{11700}{15542,02} \\
\mathrm{r}_{\mathrm{xy}}=0,753
\end{gathered}
$$

Untuk mengetahui uji signifikansi digunakan rumus

$$
\begin{aligned}
t_{\text {hitung }} & =\frac{r \sqrt{n-2}}{\sqrt{1-r^{2}}} \\
& =\frac{0,753 \sqrt{43-2}}{\sqrt{1-0,753^{2}}} \\
& =\frac{0,753 \sqrt{41}}{\sqrt{1-0,567}} \\
& =\frac{0,753.6,403}{\sqrt{0,433}} \\
& =\frac{4,820}{0,658} \\
t_{\text {hitung }} & =7,323
\end{aligned}
$$

Dari perhitungan diperoleh $\mathrm{r}_{\mathrm{xy}}=0,753$ dimana $t_{\text {hitung }}=7,323$ dan ternyata $t_{\text {hitung }}$ lebih lebih besar dari $\mathrm{t}_{\text {tabel }}$ atau 7,323>1,683. Berdasarkan rumusan hipotesis (halaman 28),
Maka $\mathrm{H}_{0}$ ditolak dan menerima $\mathrm{H}_{\mathrm{a}}$. Artinya ada hubungan yang signifikan antara Pengaruh Tingkat Pendidikan Orang Tua Terhadap Pendidikan anak di Kelurahan Pinasungkulan Kecamatan Ranowulu Kota Bitung.

\section{PEMBAHASAN}

Dari hasil pengujian hipotesis dilakukan dengan menggunakan rumus Pearson Product Moment. Dari perhitungan yang telah dilakukan diperoleh $r_{x y}=0,753$. Kemudian dilanjutkan mengukur keberartian koefisien dengan menggunkan uji-t, dengan memperoleh hasil $\mathrm{t}_{\text {hitung }}=7,323$. Dengan membandingkan $\mathrm{t}_{\text {hitung }}$ dengan $t_{\text {tabel }}$ atau 7,323 dengan 1,683. Karena $t_{\text {hitung }}$ lebih besar dari $t_{\text {tabel }}$ atau 7,323 > 1,683 maka menerima $\mathrm{H}_{\mathrm{a}}$ artinya Terdapat pengaruh yang signifikan antara Tingkat Pendidikan Orang Tua terhadap Pendidikan anak di Kelurahan Pinasungkulan Kecamatan Ranowulu Kota Bitung dan menolak $\mathrm{H}_{0}$ yaitu Tidak Terdapat Pengaruh Yang Signifikan Antara Tingkat Pendidikan Orang Tua terhadap Pendidikan Anak.

Pada bagian ini akan dibahas sehubungan dengan hasil penelitian dan analisis data yang diperoleh kemudian dihubungkan dengan kajian teori yang dikemukakan. Hasil penelitian memperlihatkan bahwa pengaruh tingkat pendidikan orang tua berpengaruh terhadap pendidikan anak. Hal ini terlihat dari hasil thitung $=7,323$ dan signifikan. Hasil penelitian ini sejalan teori pendidikan.

1. Pendidikan secara etimologis berasal dari kata dasar 'didik' yang mendapat imbuhan awalan dan akiran pe-an. Berubah menjadi kata kerja 'mendidik' yang berarti membantu anak untuk menguasi aneka Pengetahuan, ketrampilan, sikap, dan nilai yang diwarisi dari keluarga dan masyarakatnya.

2. Secara terminologis atau arti konsep sebagaimana dikemukakan oleh para ahli. Crow and Crow, pendidikan diartikan sebagai proses yang berisi berbagai macam kegiatan yang cocok bagi individu untuk kehidupan sosialnya dan membantu meneruskan adat dan budaya serta kelembagaan sosial dari generasi ke generasi. Ki Hajar Dewantara adalah salah satu ahli pendidikan dari Indonesia mengartikan pendidikan sebagai usaha menuntun segenap 
kekuatan kodrat yang ada pada anak baik sebagai individu manusia maupun sebagai anggota masyarakat agar dapat mencapai kesempurnaan hidup. Hal yang sama diungkapakan oleh Raka Joni yang menuturkan bahwa pendidikan adalah upaya sadar yang diarahkan untuk mencapai perbaikan di segala aspek kehidupan manusia.

3. Makna pendidikan secara yuridis atau perundang-undangan yang berlaku, dapat disimak dari dua undang-undang pendidikan yang berlaku terakhir di Indonesia. Undangundang Republik Indonesia Nomor 2 tahun 1989 tentang Sistem pendidikan Nasional, menyebutkan "Pendidikan adalah upaya sadar yang diarahkan untuk mempersiapkan peserta didik melalui kegiatan pengajaran, bimbingan dan/atau latihan bagi perannya di masa yang akan dating”. Sedangkan undang-undang Republik Indonesia Nomor 20 Tahun 2003 tentang Sistem pendidikan Nasional menyebutkan: "Pendidikan adalah usaha sadar dan terencana untuk mewujudkan suasana belajar dan poses pembelajaran agar peserta didik secara aktif mengembangkan potensi dirinya untuk memiliki kekuatan spiritual keagamaan, pengendalian diri, kepribadtan, kecerdasan, akhlak mulia, serta ketrampilan dibutuhkan bagi dirinya, masyarakat dan bangsa".

Orang tua Dalam kamus besar bahasa Indonesia (Poerdarmita, 1987:688) artinya ayah dan ibu. Dalam pendidikan orang tua memegang peranan yang penting dan amat berpengaruh atas pendidikan anak-anaknya. Hubungan dan tanggung jawab orang tua kepada anak, maka pendidikan itu pada dasarnya tidak bisa dipikulkan kepada orang lain, sebab guru dan pemimpin umat umpamanya, dalam memikul tanggung jawab pendidikan yang dipikul oleh para pendidik selain orang tua adalah merupakan pelimpahan dari tanggung jawab orang tua yang karena satu dan lain hal tidak mungkin melaksanakan pendidikan anaknya secara sempurna.

Jalur pendidikan adalah wahana yang dilalui peserta didik untuk mengembangkan potensi diri dalam suatu proses pendidikan yang sesuai dengan tujuan pendidikan. Menurut UU Sisdiknas No. 20 tahun 2003 pasal 13, ayat 1,
Jalur pendidikan terdiri atas pendidikan formal, nonformal, dan informal yang dapat saling melengkapi dan memperkaya. Jalur pendidikan formal pada umumnya menunjuk pendidikan persekolahan, pendidikan nonformal dikaitkan dengan paket pendidikannya berjangka pendek, setiap program pendidikannya merupakan suatu paket yang sangat spesifik dan biasanya lahir dari kebutuhan yang mendadak sedangkan pendidikan informal adalah jalur pendidikan melalui keluarga dan lingkungan.

Jenis pendidikan adalah kelompok yang didasarkan pada kekhusan tujuan pendidikan sratu satuan pendidikan. Jenis pendidikan mencakup pendidikan umum, kejuruan, akademi, profesi, vokasi, keagamaan, dan khusus. Pendidikan umum merupakan pendidikan yang mengutamakan perluasan pengetahuan dan peningkatan keterampilan peserta didik dengan pengkhususan yang diwujudkan pada tingkat-tingkat akhir masa pendidikan. Pendidikan kejuruan merupakan pendidikan yang mempersiapkan peserta didik untuk dapat bekerja dalam bidang tertentu.

Jenjang pendidikan formal terdiri atas pendidikan dasar, pendidikan menengah, dan pendidikan tinggi. Sedangkan pada pendidikan nonformal dan informal tidak mengenal jenjang. Pendidikan dasar merupakan jeniang pendidikan yang paling dasar yang mendasari jenjang pendidikan berikutnya. Pendidikan dasar berbentuk Sekolah Dasar (SD) atau bentuk lain sederajat, Sekolah Menengah (SMP) atau bentuk lain sederajat. Pendidikan menengah terdiri atas pendidikam menengah umum dan pendidikan menengah kejuruan. Pendidikan menengah berbentuk Sekolah Menengah Atas (SMA) atau bentuk lain yang sederajat, sedangkan pendidikan menengah kejuruan berbentuk Sekolah Menengah Keiuruan (SMK) atau bentuk lain yang sederajat. Pendidikan tinggi adalah jenjang pendidikan formal setelah pendidikan menengah dan merupakan jenjang pendidikan tertinggi di Indonesia. Pendiikan tinggi mencakup program pendidikan diploma, sarjana, magister, spesialis dan doktor yang diselenggarakan oleh perguruan tinggi. Perguruan Tinggi dapat berbentuk Akademi, 
Politeknik, Sekolah Tinggi, Institut, atau Universitas.

Berbagai pandangan mengenai hakikat manusia yang berbeda-beda memandang pentingnya pendidikan sebagai berikut:

1. Pendidikan sebagai transmisi kebudayaan

2. Pendidikan sebagai pengembangan 1. kepribadian

3. Pendidikan sebagai pengembangan akhlak mulia serta religious

4. Pendidikan sebagai pengembangan warga 2 . negara yang bertanggungjawab

5. Pendidikan sebagai mempersiapkan pekerjapekeria yang terampil dan produktif

6. Pendidikan adalah pengembangan pribadi paripurna atau seutuhnya
7. Pendidikan sebagai proses pembentukan manusia baru

\section{KESIMPULAN}

Dari hasil analisis data dapat ditarik beberapa kesimpulan seperti:

Tingkat pendidikan orang tua memiliki hubungan signifikan pengaruh terhadap Pendidikan Anak di Kelurahan Pinasungkulan Kecamatan Ranowulu Kota Bitung.

Semakin tinggi tingkat pendidikan orang tua semakin tinggi kesadaran terhadap pendidikan anak di Kelurahan Pinasungkulan Kecamatan Ranowulu Kota Bitung.

\section{DAFTAR PUSTAKA}

Arikunto, Suharsimi. Dkk. (2008). Evaluasi Program Pendidikan. Jakarta: Bumi Aksara.

Dirto, Hadisusanto, dkk. (1995). Pengantar Ilmu Pendidikan. Yogyakarta: FIP IKIP Yogyakarta.

Djohar, As'ari. (2007). Pendidikan Teknologi dan Kejuruan. Bandung: PT. Imperial Bhakti Utama.

Faisal, Sanapiah (1981). Pendidikan Luar Sekolah. Surabaya. Usaha Nasional.

Haryono, Suyono. (1993). Pembangunan Kesejahteraan Sosial di Indonesia. Jakarta: BKKBN.

Joni, Raka T. (1992) Pokok-pokok Pikiran Mengenai Pendidikan Guru. Jakarta: konsorsium pendidikan, Ditjen Dikti

Mely S.S. Rifai. (2000). Pendidikan Keluarga. Bandung: Pascasarjana UPI

Ngalim Purwanto. (1997). Ilmu Pendidikan Teoritis dan Praktis. Bandung: PT Remaja Rosdakarya.

Peraturan Pemerintah Republik Indonesia Nomor 19 Tahun 2005 tentang Standar Pendidikan Nasional. Jakarta: Departemen Pendidikan Nasional.

Purwadarmita. W. J.S. (1987). Kamus Umum Bahasa Indonesia. Jakarta: Balai Pustaka.

Pidarta, Made. (2004). Manajemen Pendidikan Indonesia. Jakarta: Rineka Cipta.

Riduwan. (2004). Metode dan Teknik Menyusun Tesis. Bandung: Alfabeta.

Rohman, Arif. (2013). Memahami Ilmu Pendidikan. Yogyakarta. Aswaja Persindo

Soedirjarto. (2007). Pendidikan Dalam Pendidikan Nasional. Bandung: PT. Imperial Bhakti Utama

Sugiono. (2008). Metode Penelitian Kualitatif, Kuantitatif dan $R \&$ D. Bandung: Alfabeta.

Supardan, Dadang. (2005). Pendidikan Multibudaya. Bandung: PT. Imperial Bhakti Utama

Surachmat, Winarno. (1982). Pengantar Penelitian Ilmiah. Bandung Tarsito.

Suwarno, Wiji. (1992). Dasar-Dasar Ilmu Pendidikan. Jogjakarta: Ar-ruzz Media

Tilaar, H.A.R. (2004). Paradigma Baru Pendidikan Nasional. Jakarta: Rineka Cipta.

dan Riant Nugroho (2006). Kebijakan Pendidikan. Jakarta: Rineka Cipta.

Undang-Undang Nomor 2 Tahun 1989 tentang Sistem Pendidikan Nasional. Jakarta: Departemen Pendidikan Nasional.

Undang-Undang Nomor 20 Tahun 2003 tentang Sistem Pendidikan Nasional. Jakarta: Departemen Pendidikan Nasional. 